DOI: $10.33067 /$ SE.1.2019.03

Markéta Votoupalová`

\title{
Construction of Solidarity: Czech and Polish Approach to Refugees in the EU Context
}

\begin{abstract}
The article deals with the concept of solidarity in the context of the current refugee crisis. Specifically, employing the Discourse-Historical Approach, it explores how solidarity is constructed in the discourse of the EU and in two member states, in Poland and in the Czech Republic which have been very critical of the EUropean approach to refugees from the beginning of the refugee crisis in 2015. As the findings suggest, relocations seem to be the only contested aspect of a more complex solution. On all other initiatives, there is an agreement between the EU and Poland and the Czech Republic even though the discourse might seem escalated at first sight. Moreover, drawing on the theoretical overview, the balancing of solidarity as a value with national interests and focus on security seems to be in line with the theoretical conceptualisation of international solidarity.
\end{abstract}

Key words: Refugee Crisis, EU, Solidarity, Refugee Quota System, Relocations, Discourse-Historical Approach

\section{Introduction}

Since the EU proposed the refugee quota system in 2015 to help ease the countries at the external EU border of the burden caused by the recent increase in incoming people, Poland and the Czech Republic have been among the most vocal opponents of it. Even though Poland decided to approve the plan in the end, both countries have criticised the idea heavily. The core of the quota system and also the root of the dispute seems to be the matter of solidarity. Whereas the EU leaders keep stressing that solidarity is a necessary precondition for a proper functioning of the Common European Asylum

^ Markéta Votoupalová - University of Economics, Prague, e-mail: votoupalova.marketa@gmail.com, ORCID: 0000-0003-3974-0981. 
System and all member states must help each other in case of need, Poland and the Czech Republic argue that the quota system is malfunctioning since the refugees themselves are not interested in being relocated to these two countries. Both Polish and Czech politicians stress the necessity to take care of their own citizens first and oppose the idea of being told what to do by the 'Brussels elites'. This being said, both countries insist that they still act in the spirit of solidarity and consider it to be very important for the EU integration. Their perception of solidarity, however, seems to be much different from how it is understood by the EU representatives.

Drawing on scholarly literature on the concept of solidarity, it is indeed very difficult to define it. There is not a single all encompassing and unambiguous conceptualisation. How solidarity is perceived, seems to depend on the context and to be rather subjective. Hence, the main aim of this article is to explore how solidarity is constructed and understood in the context of the current refugee crisis in the EU and to what degree it differs in the discourse of the EU and the two selected member states. Many articles discussing both the concept of solidarity and the approach of Poland and the Czech Republic to the refugee issue have been published lately. However, a specific focus on discursive construction of solidarity on a particular empirical case study is rather unique. Also the international aspect of solidarity remains rather underresearched. A special attention is given to the sustainability of the Czech and Polish critical approach within the EU context.

Since the focus of this study lies in analyzing how solidarity is discursively constructed, the methodological background develops on the Discourse-Historical Approach which enables to explore solidarity in a broader socio-political context. The article proceeds as follows: first, the methodology and data are presented. Secondly, scholarly conceptualisations of solidarity are introduced. Thirdly, the EU approach to the current refugee situation is explained and fourthly, attention is paid to the Czech and Polish attitude. Following up on the theoretical basis of the study, all empirical sections are seen through the lense of solidarity.

\section{Research Puzzle and Research Design}

As already mentioned, the main focus of this study is to explore the seeming contradiction in how solidarity is perceived by the EU and by Poland and the Czech Republic. Particularly, the following research questions will be answered:

- In the context of the current refugee crisis, how is solidarity perceived by the EU? 
- Is the construction of solidarity in Poland and the Czech Republic different? If so, in what aspects?

- Is the EU membership of these two countries sustainable despite the possible contradiction in how solidarity is perceived or, in other words, is solidarity a necessary precondition for a sustainable EU refugee policy or may the differences further intensify the idea of a two-speed EU?

The Discourse-Historical Approach (DHA) was selected as appropriate since it enables to study the connection between the form and function of a specific type of communication. ${ }^{1}$ The DHA explores both the micro-level of particular texts that the analysed discourse consists of and the meso- and macro-level of their contextualisation. ${ }^{2}$ The focus on context is significant for the DHA and highlights its interdisciplinarity as discourse is not analysed from a solely linguistic perspective, but also in a socio-political context. ${ }^{3}$

The analysis proceeds on two levels. Firstly, the entry-level analysis aims at identifying discursive topics and hence, can be understood as a thematic analysis. Secondly, the in-depth analysis explores discursive strategies, particularly how social actors are represented and what type of argumentation they use. Especially the argumentation strategies, called topoi, are very useful to examine how solidarity is perceived by particular actors. Topoi are to be understood as linguistic and cognitive processes ascribed to specific situations, for instance to defend what is right and wrong or to intetionally manipulate. ${ }^{4}$ Topoi are in fact argumentation schemes or headings under which particular arguments can be assigned. To sum up, topoi help understand how the scrutinised discourse is presented. ${ }^{5}$ Whereas topics are usually evident and explicit, topoi are often used implicitly and the process of their identification can be demanding. ${ }^{6}$ In this article, an open coding process lead by data was used to identify both topics and topoi. ${ }^{7}$

1 R. Wodak, M. Krzyżanowski, Qualitative Discourse Analysis in the Social Sciences, Palgrave Macmillan, Basingstoke; New York 2008, p. 1.

2 M. Krzyżanowski, International leadership re-/constructed? Ambivalence and heterogeneity of identity discourses in European Union's policy on climate change, "Journal of Language and Politics“, vol. 14:1, pp. 111-112.

3 R. Wodak, M. Krzyżanowski, op. cit., p. 2.

${ }^{4}$ M. Reisigl, Argumentation Analysis and the Discourse-Historical Approach. A Methodological Framework, in: Contemporary Critical Discourse Studies, ed. C. Hart, P. Cap, Bloomsbury, London 2014, p. 70.

5 M. Krzyżanowski, op. cit., p. 121.

6 M. Reisigl, op. cit., p. 75.

7 G. Gibbs, Analyzing Qualitative Data, SAGE, Los Angeles2018, pp. 61-62. 
The choice of Poland and the Czech Republic as case studies follows from the overall theme of this special journal number. Analysed data cover the time period from late Spring 2015, when the number of incoming refugees to the EU escalated, to July 2018 when the data collection was finished. This time span allows to explore the development of the discourse on solidarity in time, as well. In order for the analysis to be detailed, only the political discourse was explored. To ensure representativeness and complexity of the study, various discourse genres were examined, namely political documents, reports and programs as well as statements of relevant political leaders (Presidents of the European Council, Commission and Parliament and the Commissioner for migration in case of the EU and Prime Ministers and Ministers responsible for migration in Poland and the Czech Republic). The data were retrieved from official websites of the relevant institutions. Direct quotations were preferred to paraphrases to ensure reliability.

\section{Conceptualisation of Solidarity}

Both scholars and politicians very often explain the problems within the EU by the lack of solidarity. Although this is not a new phenomenon and such complaints and criticisms are to be found in the past as well, ${ }^{8}$ the current debates seem to have gained a new impetus. Whereas those claiming that solidarity regarding dealing with the current refugee flows is insufficient stress the difference between solidarity as a value to be cherished and selfish national interests, Polish and Czech politicians insinuate that one can express solidarity and defend their national interests at the same time. In order to understand how such discrepancies are possible, we start with introducing how solidarity is explored and seen by scholars. Historically, solidarity has had many meanings and connotations. Comte, stressing its moral and affective aspects, puts it into a social and economic context. In the socialist tradition, solidarity represents asymmetrical power relations and oppression, for liberal sociologists, solidarity explains social integration of societies. ${ }^{9}$

8 Cf. J. Apap, S. Carrera, Maintaining Security within Borders: Towards a Permanent State of Emergency in the EU?, "CEPS Policy Briefs", no. 4/2003; G. Campesi, The Arab Spring and the Crisis of the European Border Regime: Manufacturing Emergency in the Lampedusa Crisis, "EUI RSCAS Working Papers" no. 59/2011; S. Carrera et al., A Race against Solidarity. The Schengen Regime and the Franco-Italian Affair, "CEPS“, vol. April/2011; G. Cornelisse, What's Wrong with Schengen? Border Disputes and the Nature of Integration in the Area Without Internal Borders, "Common Market Law Review“, vol. 51/2014, pp. 741-770.

9 M. Pensky, The ends of solidarity: discourse theory in ethics and politics, State University of New York Press, Albany 2008. 
Currently, the research into the notion of solidarity has gained much attention but remains rather fragmented and dependent on the context: solidarity can be exlored on various levels (family or state) and from different angles (traditional, affective, as a normative concept). ${ }^{10}$ Some scholars introduce their own typologies of solidarity. Shelby ${ }^{11}$ differentiates between a robust solidarity which makes people feel obliged to act and an expressional solidarity which motivates to act but is not binding. Gould, ${ }^{12}$ following up on Bayertz, offers a typology consisting of solidarity as a kind of fraternity, or as an anonymous kind of bond holding societies together, or as a core of a welfare state or, lastly, as a way how people can defend their shared interests. Very often, solidarity is seen either as project-driven (rational) or, contrarily, as emotional or affective. ${ }^{13}$ Additionally, De Beer and Koster ${ }^{14}$ distinguish between informal solidarity in a society where people know each other and formal solidarity mediated by institutions.

Furthermore, it must be stated, that although solidarity is studied from different angles, such as moral, ${ }^{15}$ racial, ${ }^{16}$ social ${ }^{17}$ or political, ${ }^{18}$ the research into the international aspect of solidarity, is still limited. ${ }^{19}$ How-

10 W. Rehg, Solidarity and the Common Good: An Analytic Framework, "Journal of Social Philosophy“, vol. 38:1/2007, pp. 7-21.

11 T. Shelby, We who are dark: the philosophical foundations of Black solidarity, Belknap Press, Cambridge, MA 2012.

12 C. Gould, Transnational Solidarities, "Journal of Social Philosophy“, no. 38:1/2007, pp. 148-164.

13 G. Crow, Social solidarities. Theories, identities, and social change, Open University Press, Filadelfie2002; P. De Beer, F. Koster, Sticking Together or Falling Apart? Solidarity in an Era of Individualization and Globalization, Amsterdam University Press, Amsterdam2009.

14 P. De Beer, F. Koster, op. cit.

15 J. Harvey, Moral Solidarity and Empathetic Understanding: The Moral Value and Scope of the Relationship, "Journal of Social Philosophy“, 38:1/2007, pp. 22-37.

16 D. Chong, R. Rogers, Racial Solidarity and Political Participation, "Political Behavior“, no. 27:4/2005, pp. 347-374; J. Hooker, Race and the politics of solidarity, Oxford University Press, Oxford; New York 2009; T. Shelby, op. cit.

17 G. Crow, op. cit.

18 K.P. Rippe, Diminishing Solidarity, "Ethical Theory and Moral Practice, no. 1/1998, pp. 355-374; S. Scholz, Political Solidarity and Violent Resistance, "Journal of Social Philosophy“, 38:1/2007, pp. 38-52; E. Dussel, From Fraternity to Solidarity: Toward a Politics of Liberation, "Journal of Social Philosophy“, vol. 38:1/2007, pp. 73-92.

19 L. Wilde, The Concept of Solidarity: Emerging from the Theoretical Shadows?, "BJPIR", no. 9/2007, pp. 171-181; L. May, The International Community, Solidarity and the Duty to Aid, "Journal of Social Philosophy“, no. 38:1/2007, pp. 185-203; J.-M. Coicaud, N.J. Wheeler, National Interest and International Solidarity: Particular and Universal Ethics in International Life, United Nations University Press, Tokyo, JPN 2008; E. Tulmets, Identities and Solidarity in Foreign Policy: East Central Europe and the Eastern Neighbourhood, Institute of International Relations, Prague 2012. 
ever, it is important to the issue of this paper to have a look exactly at how solidarity is conceptualised in the area of international relations. Drawing on what has been said above, solidarity is presented as rational and pragmatic rather than emotional. Indeed, it is often linked to national interests and solidarity and interests are not perceived as incompatible. On the contrary, according to Coicaud and Wheeler, ${ }^{20}$ national interests and solidarity must take each other into account. It is not possible for a state to act purely selfishly and on the other hand, solidarity is not solely about what is right or wrong but can even enhance security or interests. Similarly, Krieg ${ }^{21}$ argues that interests are not always selfish in nature and that there is a continuum between solidarity and interests which are not mutually exclusive.

All in all, even this brief introduction into the concept of solidarity demonstrates how complex and ambiguous it is. Nevertheless, it is possible to identify some main discursive strategies. Regarding social actors, scholars tend to foreground states as the main actors. The most frequent argumentation strategy is the topos of otherness: solidarity is always bound to a specific community which shares their common interests. In the case of international solidarity, the topos of usefulness is highlighted which grasps the idea that solidarity is always linked to promoting interests. If there is no shared interest, solidarity will not occur. However, as Shelby ${ }^{22}$ stresses, solidarity can survive incompletely shared interests. Overall, international solidarity seems to be rather pragmatic.

\section{EU Approach to the Refugee Flows}

Refugee flows became one of the main political and media issues in Summer 2015. Despite this not being a completely new topic, the increase in numbers of incoming refugees was significant during 2015 and 2016 compared to the previous years. Although the EU was criticised for not having acted quickly enough, the first plans to handle the emergency situation were developed immediately. Already in June 2015, the first proposal of refugee quotas was voted upon and during Autumn, the plan to enhance the capacity of Frontex was proposed. Unfortunately, it took a long time for these initiatives to be implemented and some member states undertook national steps, such as reintroducing internal border controls and even building fences, in the meantime.

20 J.-M. Coicaud, N.J. Wheeler, op. cit.

21 A. Krieg, Motivations for Humanitarian Intervention: Theoretical and Empirical Considerations, Springer, Heidelberg 2013.

22 T. Shelby, op. cit. 
The main document summarising the goals of the EU is the European Agenda on Migration which was put forward by the Commission in May 2015. The agenda is presented as "a coherent and comprehensive approach to reap the benefits and address the challenges deriving from migration". ${ }^{23}$ Its "immediate imperative is the duty to protect those in need, to avert further loss of life" and to "address the root causes of migration".24 "Europe should continue to be a safe haven for those fleeing persecution" and uphold its "international commitments and values" but, at the same time, secure its borders. ${ }^{25}$ These quotations show a clear effort of the EU to achieve a balance between ensuring human rights, including refugee rights and, at the same time, securing its borders. The first argumentation strategy could be called atopos of human right and the latter a topos of security. Also, the EU insists on upholding its legal commitments, both internally as EU acquis but also externally in the sense of international law. Hence, atopos of rules appears. Another topos used by the EU could be labelled as a topos of burden sharing since the core of the European approach is thecooperation between all member states "in accordance with the principles of solidarity and shared responsibility “. ${ }^{26}$ Overall, in spite of the fact that the notion of solidarity is not developed in any detail explicitly, specific argumentation strategies can be identified in the agenda.

Particularly, the agenda is divided into two main sections. The first part is called Immediate Action and aims at saving lives at sea, fighting against smugglers, relocation and resettlement, partnership with third countries and helping member states at the EU external border. According to the agenda, "Europe cannot stand by whilst lives are being lost" and must show a "welcome solidarity" (a strong topos of human rights). ${ }^{27}$ Simultaneously, everything must be done to prevent irregular migration and human smuggling (topos of security). Relocations are presented "a permanent system for sharing the responsibility for large numbers of refugees and asylum seekers among Member States' in which all 'Member States will need to show solidarity and redouble their efforts to assist those countries on the frontline" ${ }^{28}$ Another measure how to help those states at the external border is to send them financial help and create hotspots. Similarly, the member states should help UNHCR with reset-

23 European Agenda on Migration, http://eur-lex.europa.eu/legal-content/EN/ TXT/?qid=1433336249722\&uri=CELEX:52015DC0240 (7.01.2017).

24 European Agenda on Migration, op. cit., p. 2.

25 Ibidem.

26 Ibidem.

27 Ibidem, p. 3.

28 Ibidem, p. 4. 
tlements from the most affected countries outside the EU. In both cases, the topos of burden sharing is intense.

Then, a section on long-term strategies follows which consists of several pillars to manage migration better. According to these pillars, the EU must continue to help people in need but "draw the consequences when migrants do not meet the criteria to stay" (not specified how but the EU wants to prevent irregular migration which undermines confidence in the European asylum systems and offers an easy target to critical voices). ${ }^{29}$ Then, the EU must reduce incentives for irregular migration through partnership with third countries, efficient return policy and fight against smugglers. Furthermore, the border management must be improved and help save lives at sea but also secure the external border. Again, the topos of human rights is balanced by the topos of security. The duty of the EU to protect people in need must be supported by a functioning common asylum system which will be abided by all member states (topos of rules). Last but not least, the Commission proposes a new policy on legal migration which goes beyong tackling the refugee inflows but basically appreciates migration as "an important way to enhance the sustainability of our welfare system and to ensure sustainable growth of the EU economy“. ${ }^{30}$

Particular steps followed in line with this agenda. However, an agreement across all member states was not always achieved. The quota system appeared to be the most problematic aspect of the EU approach. The idea of relocating asylum seekers goes back to the principle of the Dublin regulation. According to Dublin III, if we simplify, it is only possible to apply for asylum once in the whole EU and the country responsible for assessing an asylum application is usually the first country of entry. Logically, this system leads to a very uneven distribution of applications in the member states. After the numbers of incoming refugees increased significantly in 2015, the Commission acknowledged that the system is not sustainable and proposed an amendment to the Dublin regulation, Dublin IV. The aim of this recast was to further harmonise asylum procedures across the EU and to make the allocation of asylum seekers more even. ${ }^{31}$ The principle was supposed to be based on the number of received refugees which could not exceed $150 \%$ of each member state's fair share of asylum applications calculated from its population (50\%) and GDP (50\%). If this share was to be exceeded, all additional applicants would be relo-

\footnotetext{
29 Ibidem, p. 7.

30 Ibidem, p. 14.

31 http://eur-lex.europa.eu/legal-content/EN/ALL/?uri=CELEX:52016PC0270 (23.09.2018).
} 
cated to other member states. If such a member state refusedto accept any applicants, it could instead pay 250000 EUR per person to another state which would accept the respective person. ${ }^{32}$

However, in September 2018, when this article is written, Dublin IV is still not adopted. In the meantime, the Commission proposed the already mentioned plan on the refugee quotas. The first version proposed in June was not accepted, the second version was refused by the Czech Republic, Hungary, Slovakia and Romania and abstained by Finland but despite this accepted in September 2015. Poland voted in favour of the proposal in the end. Slovakia and Hungary even sent an official complaint to the European Court of Justice but it was judged as unsubstantiated in Autumn 2017. ${ }^{33}$ The quota system was limited in time - it lasted for two years - and was intended to include 160000 asylum applicants from Italy and Greece. ${ }^{34}$ The following graph shows that only about 31500 relocation were executed in the end which is only a small share despite the growing numbers in time.This demonstrates the difference between the EU approach which stresses the topos of burden sharing and the member states which do not feel bound by this idea. Whereas the EU aims at helping the member states in need and wants to ensure acceptable living conditions to refugees, the member states seem to prefer their own interests (see the next chapter).

Apart from the relocation system, the Commission proposed to resettle 20000 refugees from the most affected third countries outside the EU. By September 2017, 17000 refugees were successfully resettled, most of them within the EU-Turkey agreement. Although this agreement, especially the 1:1 mechanism, is often criticised for perceiving refugees as trading goods and for being in breach with international (humanitarian) law, 35 from a pragmatic perspective, it is a success since the illegal crossings (and also deaths at sea) from Turkey to Greece decreased significantly. ${ }^{36}$ The EU wants to negotiate a similar kind of agreement with Libya, which

32 https://ec.europa.eu/home-affairs/sites/homeaffairs/files/what-we-do/policies/european-agenda-migration/background-information/docs/20160504/the_reform of_the_dublin_system_en.pdf (23.09.2018); https://www.ceps.eu/publications/mediterranean-migrants-little-help-offer-italy (23.09.2018).

33 Case C-647/15 from 2. December 2015 and case C-643/15 from 3. December 2015.

34 https://www.ceps.eu/system/files/TFR\%20EU\%20Border\%20and\%20Coast\%20 Guard\%20with\%20cover_0.pdf (23.09.2018); https://www.ceps.eu/publications/rethinking -asylum-distribution-eu-shall-we-start-facts (23.09.2018).

35 https://www.ceps.eu/system/files/EU-Turkey\%20Deal.pdf (23.09.2018).

36 https://ec.europa.eu/home-affairs/sites/homeaffairs/files/what-we-do/policies/european-agenda-migration/background-information/eu_turkey_statement_17032017_en.pdf (23.09.2018). 
is one of the main smuggling hubs in Africa. Also, the EU tries to adopt readmission agreements with other African countries to further reduce the number of incoming refugees. ${ }^{37}$ Whereas the numbers of incoming refugees declined during 2017, the return policy is not so successful and the vast majority of denied asylum seekers remains on the Europeal soil. ${ }^{38}$ It seems, that balancing burden sharing (helping third countries) and security is not very easy in practice.

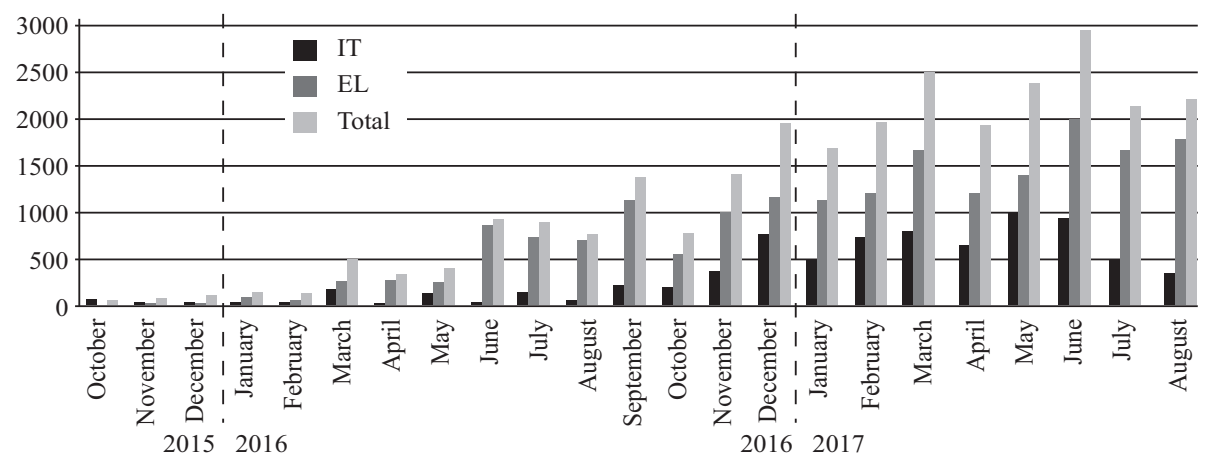

Fig. 1. Relocations from Greece and Italy

Source: https://ec.europa.eu/home-affairs/sites/homeaffairs/files/what-we-do/policies/ european-agenda-migration/20170904_factsheet_relocation_and_resettlement_en.pdf (23.09.2018).

The need for a common EU approach to the refugee issue is further stressed by the existence of the Schengen cooperation. Since there are no internal borders within the Schengen Area and anybody can travel freely across it, the member states are very closely dependent on each other. Without sufficient trust and agreement on common solutions, some member states reacted by reintroducing their internal border controls. Germany did so already in September 2015 and was soon followed by Austria, Sweden, Norway and Denmark. ${ }^{39}$ All countries justified their decision by fear from not being able to manage migra-

37 https://ec.europa.eu/home-affairs/sites/homeaffairs/files/what-we-do/policies/european-agenda-migration/20170704_factsheet_-_central_mediterranean_route_commission_action_plan_to_support_italy_and_stem_flows_en.pdf (23.09.2018).

$38 \mathrm{http}: / / w w w . c s s . e t h z . c h / e n / s e r v i c e s /$ digital-library/articles/article.html/2318296 f-e06e-4536-9c51-c6eb370c1068/pdf (23.09.2018).

39 Council Document 11986/15; Council Document 12110/15; Council Document 14996/15; Council Document 14047/15. 
tion flows. ${ }^{40}$ Even though both Poland and the Czech Republic also considered internal reintroductions, they did not make the final decision to do so. Despite the number of reintroductions being limited, it shows how difficult it is for the EU to push through the idea of (selfless) burden sharing.

In order to save the Schengen Area from collapsing, the EU proposed to strengthen the Frontex agency. The ideaof a European Border and Coast Guard (EBCG) with a bigger budget, more employees and an enhanced capacity in controlling the external border and return policy dates back to 2015 but finally came into force in September $2016 .{ }^{41}$ Apart from Frontex joint operations in the Mediterranean and Aegean sea (e.g. Triton and Poseidon operations), the EUsupports fight against smugglers (EUNAFVOR MED Sophia operation) and supports Italy and Greece financially. ${ }^{42} \mathrm{Also}$, the EU strengthened the role of security databases, such as the Schengen Information System II, Europol and Eurojust databases, and proposed new databases, especially the Passenger Name Record and Entry-Exit System..$^{43}$ The topos of security prevails regarding these initiatives since they aim at preventing crime, irregular migration and securing EU external borders.

It follows from this chapter, that based on the entry-level analysis, it can be said that in general, the European approach has an internal dimension (financial help to the most affected member states, especially Italy and Greece, and relocations) and an external dimension (return policy, readmission agreements, financial help to third countries of origin and transit and agreements with Turkey and Libya). Both dimensions have short- and long-term aspects. These topics are presented using various argumentative strategies, especially the topoi of burden sharing, rules, human rights and security (see the table below for a systematic presentation of both topics and argumentation strategies). The results of both levels of the DHA analysis will now be compared with the Polish and Czech approach.

40 Slovenia also reintroduced its internal borders but abolished them after a month. Belgium and France reimposed their controls due to fear from terrorism.

41 Regulation (EU) 2016/1624 of the European Parliament and of the Council of 14 September 2016 on the European Border and Coast Guard.

42 Cf. https://www.ceps.eu/system/files/TFR\%20EU\%20Border\%20and\%20Coast \%20Guard\%20with\%20cover_0.pdf (23.09.2018).

${ }^{43} \mathrm{http}$ ://www.consilium.europa.eu/en/policies/fight-against-terrorism/passengername-record/ (23.09.2018). 


\section{Tab. 1. EU construction of solidarity}

\begin{tabular}{|c|l|l|}
\hline Topos & \multicolumn{1}{|c|}{ Argumentation strategy } & \multicolumn{1}{|c|}{ Topics } \\
\hline $\begin{array}{l}\text { Burden } \\
\text { sharing }\end{array}$ & $\begin{array}{l}\text { The EU and its member states must help the } \\
\text { most affected states like Italy and Greece by } \\
\text { relocating some refugees to other member } \\
\text { states and by helping them control the } \\
\text { external EU border; furthermore the most } \\
\text { affected third countries must be helped } \\
\text { too, by sending them financial help and by } \\
\text { resettling refugees }\end{array}$ & $\begin{array}{l}\text { Refugee quotas, } \\
\text { Schengen, external } \\
\text { border control, } \\
\text { cooperation } \\
\text { with 3. countries }\end{array}$ \\
\hline Rules & $\begin{array}{l}\text { All member states must accept common } \\
\text { EU rules, such as the Common European } \\
\text { Asylum System and the Schengen Acquis }\end{array}$ & $\begin{array}{l}\text { Refugee quotas, } \\
\text { international law }\end{array}$ \\
\hline Security & $\begin{array}{l}\text { The EU and its member states must protect } \\
\text { the external borders, prevent irregular } \\
\text { migration and fight against smugglers }\end{array}$ & $\begin{array}{l}\text { Schengen, external } \\
\text { border control, } \\
\text { databases, EU-Turkey } \\
\text { agreement, fight } \\
\text { against smugglers and } \\
\text { irregular migration, } \\
\text { return policy }\end{array}$ \\
\hline $\begin{array}{l}\text { Human } \\
\text { rights }\end{array}$ & $\begin{array}{l}\text { The EU and its member states must } \\
\text { protect human rights of refugees; economic } \\
\text { migration seen as an opportunity }\end{array}$ & $\begin{array}{l}\text { Refugee rights, right } \\
\text { to asylum, economic } \\
\text { migration }\end{array}$ \\
\hline
\end{tabular}

Source: Author's own.

\section{Czech and Polish Approach: Differences and Similarities}

Neither the Czech Republic nor Poland were among the member states most affected by the refugee crisis. The following two graphs demonstrate this fact. It follows from the first figure that the increase in asylum seekers was quite significant in 2015 and 2016, the latter graph shows that the numbers of asylum applications in both countries were very low.However, both countries were very vocal on their objections to the EU approach towards refugees. In this section, their actions and discourse with regard to the concept of solidarity will be analysed and compared to the EU. 
M. Votoupalová, Construction of Solidarity: Czech and Polish Approach to Refugees...

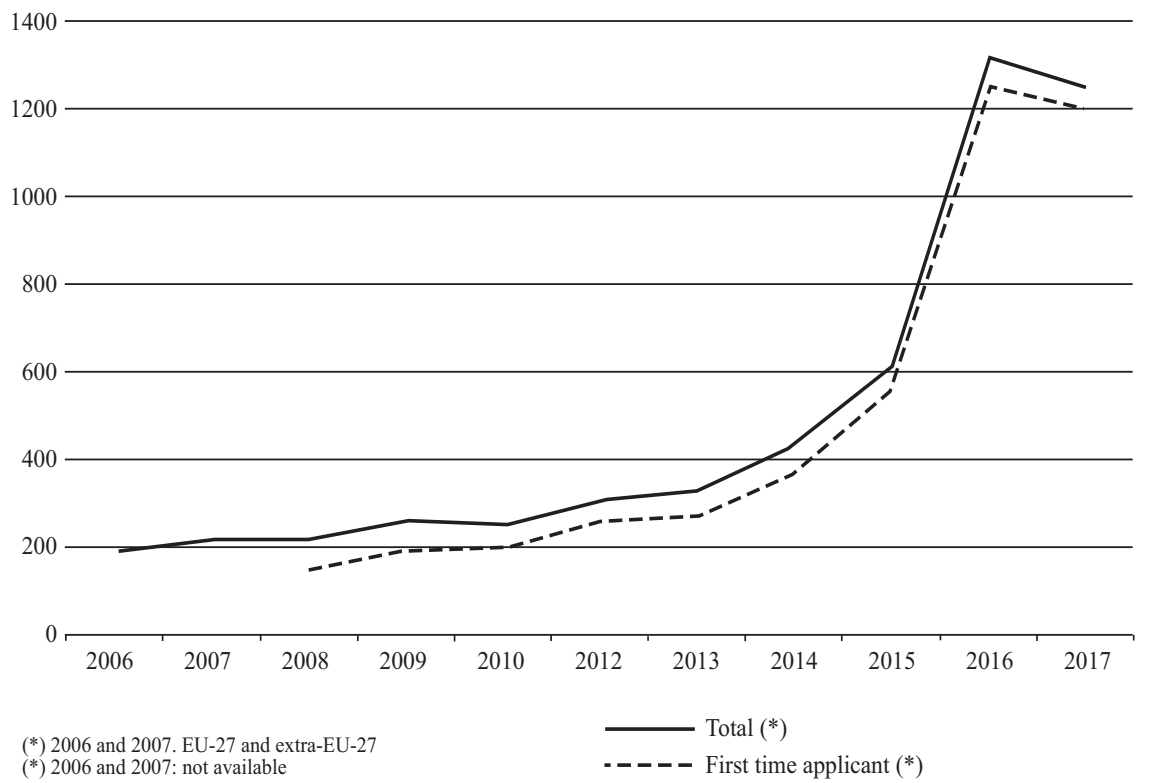

Fig. 2. Asylum applications in the EU

Source: http://ec.europa.eu/eurostat/statistics-explained/index.php/Asylum_statistics (23.09.2018).

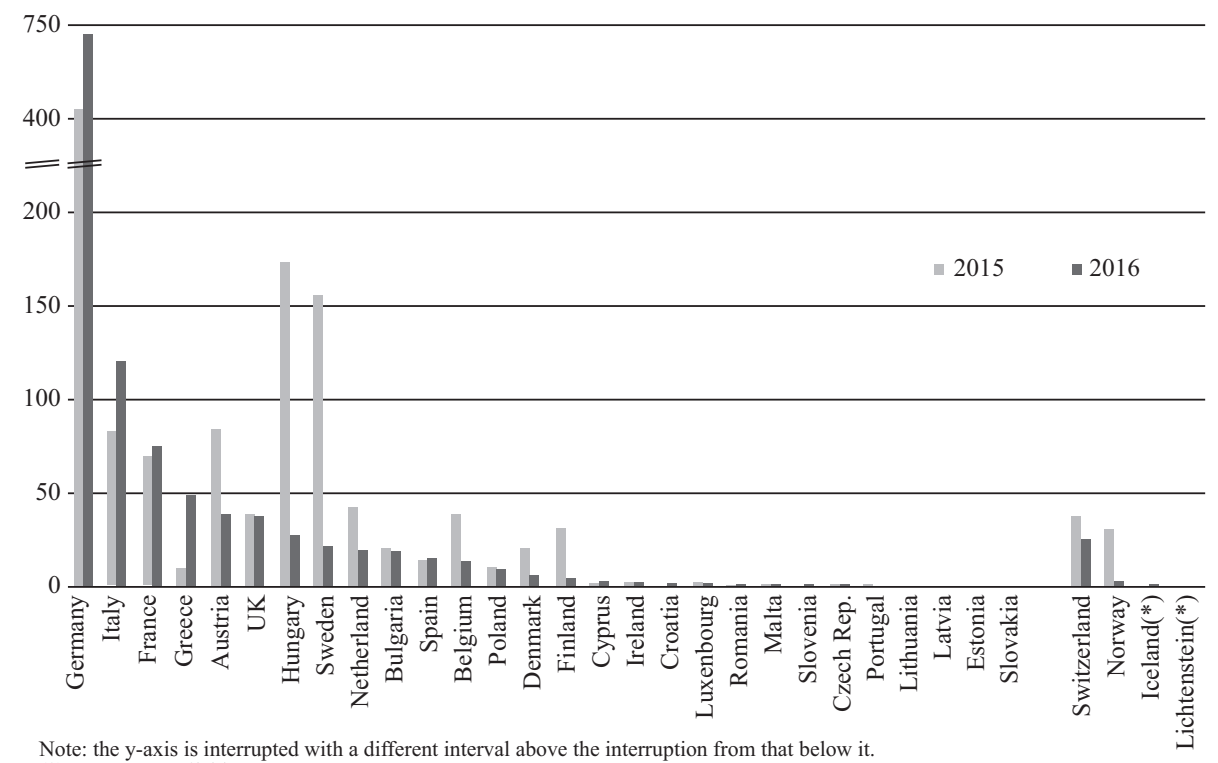
(*) 2015: not available

\section{Fig. 3. Asylum applications in EU member states}

Source: http://ec.europa.eu/eurostat/statistics-explained/index.php/Asylum_statistics (23.09.2018). 
Both countries criticised especially the refugee quota system. Based on the population, GDP and already received number of refugees, the Czech Republic was supposed to accept 2691 refugees and Poland 6182 refugees. These are not very high numbers but all Czech governmental parties agreed that quotas are not and cannot be a functioning solution to the current crisis and refused them openly. Most of the opposition parties, especially the communist party, the conservative ODS and right-winged populist SPD were even more critical of relocations, the only party explicitly in favour of the relocation system was the conservative-liberal TOP09. The sharpest critics were the minister of finance A. Babis (ANO) and social-democratic minister of interior M. Chovanec (ČSSD). According to Babiš, the goal of the Czech Republic is: "to persuade European politicians to stop being politically correct and start thinking about security of their own citizens and not about humanitarian help which is important but easy to be abused". ${ }^{44}$ In this citation, there is a strong focus on citizens rather than refugees which is typical of the Czech construction of the topos of human rights, as opposed to the EU.

The prime minister B. Sobotka adopted a more nuanced position when he claimed that refusing quotas does not mean that the Czech Republic does not want to express solidarity but rather that it is a refusal of an order "from above", meaning from Brussels. He argued that he would rather help on a voluntary basis and already in 2015 promised to accept 400 persons from third countries and 1100 persons from Italy and Greece. ${ }^{45}$ Sobotka said about the quota system: "I'm convinced that by accepting this proposal, the Commission doesn't respect [...] that the member states agreed the recolation mechanism would be voluntary“". ${ }^{46}$ Despite this criticism and despite stressing the importance of national sovereignty, Sobotka acknowledges the importance of a common EU approach: "immigration policy is within the competence of particular national governments and

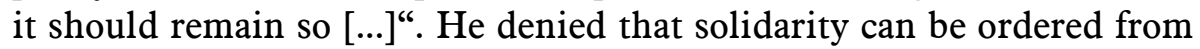
above but acknowledged that "we must participate in finding a European solution" ${ }^{47} \mathrm{He}$ added that "our aim isn't to put the Czech Republic into isolation in the EU but, to the contrary, to be able to put our arguments forward“". ${ }^{48}$ Hence, the Czech Republic wants to comply with the EU rules

44 https://www.novinky.cz/domaci/386512-pokud-neuzavreme-hranice-schengense-rozpadne-tvrdi-babis.html (23.09.2018).

45 https://apps.odok.cz/attachment/-/down/IHOA9YFF864R (23.09.2018).

$46 \mathrm{https} / /$ www.vlada.cz/cz/clenove-vlady/premier/projevy/vystoupeni-premiera-bohuslava-sobotky-v-poslanecke-snemovne-k-tematu-migracni-krize--131926/ (23.09.2018).

47 https://www.psp.cz/sqw/interp.sqw?o=7\&s $=44$ (23.09.2018).

48 https://www.psp.cz/sqw/interp.sqw?o=7\&s $=33(23.09 .2018)$. 
(topos of rules) but only if its sovereignty to decide about accepting refugees is maintained. In line with this moderate approach, the Czech Republic decided not to sue the EU for having acted illegally as Slovakia and Hungary did (see above). Despite that, the Czech Republic was strongly criticised by the Commission since minister Chovanec explicitly stated that, after having received 12 refugees, we would not accept a single one any more. Also Babišs's rhetoric escalated into considering a complaint against quotas even if we were to be punished by sanctions. According to him: "We must take care of security of the Czech citizens. Even if threatened by sanctions". 49

Another reason why the Czech Republic rejected relocations was the perception that the refugees themselves do not want to come here: "a binding and permanent quota system can't be functional, in particular because the respective people aren't willing to settle in countries where they don't want to be" ${ }^{50}$ as Sobotka said. By the same token, Babiš argued: "Indeed, the refugees don't want to come to the V4 countries and the EU should realisethat" ${ }^{51}$ As a consequence, Czech politicians prefer to accept refugees from culturally similar countries, like Ukraine. ${ }^{52}$ The topos of human rights seems to be conditioned by cultural ties.

Also, since Autumn 2015, the Czech government has repeatedly accepted financial, material and personal help for many countries in need including Hungary, Slovenia, Macedonia, Jordan and Lebanon. ${ }^{53}$ All

${ }^{49}$ A. Babiš, Facebook profile.

50 https://www.psp.cz/sqw/interp.sqw?o=7\&s=44 (23.09.2018).

51 https://www.novinky.cz/domaci/397061-cesko-muze-prijmout-syrske-uprchliky-primo-z-turecka-tvrdi-sobotka.html (23.09.2018).

52 http://www.ceskatelevize.cz/ct24/domaci/1579158-babisuv-recept-na-uprchliky -zavrit-schengen-a-nepodporovat-ekonomicke-migranty (23.09.2018).

53 Usnesení vlády České republiky ze dne 19. ř́ijna 2015 č. 843 k návrhu opatření v souvislosti s vysláním příslušníků Policie České republiky do Madarska (Resolution of the Government of the Czech Republic dated 19 October 2015 No. 843 on the draft measure in connection with the deployment of members of the Police of the Czech Republic to Hungary); Usnesení vlády Ceské republiky ze dne 2. listopadu 2015 č. 888 k vyslání prŕslušníků Policie České republiky do Republiky Slovinsko (Resolution of the Government of the Czech Republic dated 2 November 2015 No. 888 on the deployment of members of the Police of the Czech Republic to the Republic of Slovenia). Usnesení vlády České republiky ze dne 21.prosince 2015 č. 1087 o vyslání př́íslušníků Policie České republiky do Republiky Slovinsko a do Makedonské republiky a o poskytnutí peněžního daru Makedonské republice (Resolution of the Government of the Czech Republic dated 21 December 2015 No. 1087 on the deployment of members of the Police of the Czech Republic to the Republic of Slovenia and to the Republic of Macedonia and on providing a financial donation to the Republic of Macedonia); Usnesení vlády České republiky ze dne 16. března 2016 č. 235 o způsobu plnění usnesení vlády ze dne 21. prosince 2015 č. 1087, o vyslání příslušníků Policie České republiky do Republiky Slovinsko a do Make- 
cooperation is bilateral, not within the EU framework. Particularly, the Czech government implemented several national plans such as the humanitarian and medical programme MEDEVAC ${ }^{54}$ or a scholarship programme for Syrian refugees. ${ }^{55}$ As Sobotka argued: "solidary initiatives developed to help third and transit countries are one of the key instruments for solving the migration crisis [...] ${ }^{\text {“. }}{ }^{56}$ Overall, he prefers "to help people in Jordan, Lebanon and Turkey rather than to let these people travel to Europe with naive and skewed ideas". ${ }^{57}$

In the EU, the Czech politicians advocated mostly in favour of enhancing external border controls. Prime minister Sobotka even proposed a few concrete initiatives on how to protect the external borders (strengthening of Frontex, development of smart borders, enhanced cooperation with Turkey as well as African and Balkan countries). Sobotka also stressed how important it is to protect Schengen, to follow the rules and to improve return policies. ${ }^{58} \mathrm{He}$ also highlighted the need to solve the roots of the problems and not their consequences. ${ }^{59}$ The topos of burden sharing is explicitly linked to third countries and help outside the EU and to external border control, not to relocations.

Overall, there is an obvious clash present in the Czech discourse in which the EU approach is boiled down to the quota system whereas the Czech politicians strive for a more complex and systematic solution.

donské republiky a o poskytnutí peněžního daru Makedonské republice (Resolution of the Government of the Czech Republic dated 16 March, 2016 no. 235 on the method of implementation of Government Resolution dated December 21, 2015 no. 1087, on the deployment of members of the Police of the Czech Republic to the Republic of Slovenia and the Republic of Macedonia and on providing a financial donation to the Republic of Macedonia).

54 Usnesení vlády České republiky ze dne 20. listopadu 2015 č. 956 o zřízení Stálého zdravotně humanitárního programu MEDEVAC (Resolution of the Government of the Czech Republic dated 20 November 2015 No. 956 on the establishment of the Permanent Health Program MEDEVAC).

55 Usnesení vlády České republiky ze dne 8. června 2016 č. 513 k vyhodnocení programu Nové elity pro Sýrii, programu stipendií vlády České republiky syrským uprchlíkům (Resolution of the Government of the Czech Republic dated 8 June 2016 No. 513 on the evaluation of the program New Elites for Syria, a program of scholarships by the Government of the Czech Republic to Syrian refugees).

$56 \mathrm{https} / /$ www.vlada.cz/cz/media-centrum/aktualne/premier-sobotka-informovalpredsedu-ek-junckera-o-vyraznem-navyseni-ceske-financni-pomoci-v-souvislosti-smigracni-krizi-136675/ (23.09.2018).

57 https://www.novinky.cz/domaci/395326-sobotka-pokud-lide-utikaji-pred-valkou -mame-povinnost-jim-pomoci.html (23.09.2018).

58 http://www.bohuslavsobotka.cz/cs/premier-sobotka-vyzval-evropske-partnery-kposileni-spoluprace-pri-ochrane-vnejsich-hranic-a-zachovani-schengenu (23.09.2018).

59 https://www.psp.cz/sqw/interp.sqw?o=7\&s $=44$ (23.09.2018). 
As the Vice-Prime Minister Bělobrádek said: "It must be a misunderstanding of the V4 opinion which is solidary and responsible“.${ }^{60} \mathrm{How}$ ever, when examined closer, there is no such clash in practice sincethe EU also agrees on the importance of preventing refugee flows and enhancing security (topos of security) and indeed, with the exception of the quota system, the Czech Republic acts in line with the EU agenda and politicians agree on the importance of solidarity. As the Prime Minister argued: "We are a country that expresses solidarity, a country that helps and I want to state clearly that we are also a country that will continue to do so" ${ }^{61}$ Hence, even though the Czech government promotes security and Czech interests, it also feels to be obliged by the EU commitments.

Even though the topos of human rights is only used very rarely, the basic commitment to accept refugees in need is not questioned. As Sobotka claims: "if people really flee from war, a there many of such kind, we are obliged to help them. Not only because of our international commitments but because we are a civilised country with a strong humanitarian tradition" ${ }^{62} \mathrm{He}$ also wants to "link the humanitarian and security aspect of the refugee crisis" ${ }^{63}$ On the other hand, Sobotka sees it as a problem that: "in the unregulated flows, there are people who need help as well as economic migrants" ${ }^{64}$ And he does not feel commited to help the latter.

In general, solidarity seems to be unproblematic if it only has an impact outside of the Czech territory. The Czech perception of solidarity aims at helping those in need but in the countries of origin rather than in the EU. For instance the report ${ }^{65}$ of the Ministry of Interior says in the introduction that the Czech approach to solidarity has always been determined by the principles of solidarity and responsibility. Specifically, solidarity is exemplified on the example of financial, personal and material help for countries affected by the refugee crisis. The document says

${ }^{60}$ https://www.novinky.cz/domaci/395982-rozhovor-renziho-v-pravu-nadzvedl-ceske -politiky.html (23.09.2018).

61 https://www.vlada.cz/cz/clenove-vlady/premier/projevy/vystoupeni-premiera -bohuslava-sobotky-v-poslanecke-snemovne-k-tematu-migracni-krize--131926/ (23.09.2018).

62 https://www.novinky.cz/domaci/395326-sobotka-pokud-lide-utikaji-pred-valkou -mame-povinnost-jim-pomoci.html (23.09.2018).

${ }^{63} \mathrm{http}: / /$ roklen24.cz/a/iYdjN/sobotka-cesko-odmita-mensi-schengen-chce-ochranu -nynejsiho (23.09.2018).

64 https://www.novinky.cz/domaci/395326-sobotka-pokud-lide-utikaji-pred-valkou -mame-povinnost-jim-pomoci.html (23.09.2018).

65 http://www.mvcr.cz/migrace/clanek/informace-vlady-cr-o-migracni-krizi.aspx (23.09.2018). 
nothing about solidarity towards refugees and little about burden sharing (only the voluntary commitment to relocate 1100 and resettle 400 refugees is mentioned). Simultaneously, Czech politicians require solidarity from other countries, especially those in the Middle East which should offer help based on cultural and social similarities with refugees and from Italy and Greece that should fulfil their responsibilities and properly check the EU external borders. In line with this, the Minister of Foreign Affairs L. Zaorálek frequently stresses that the Czech Republic is not the only country which disagrees with the quota system. ${ }^{66}$

Also the Polish public discourse has been formed by the refugee crisis since 2015 even though Poland, together with Hungary, did not accept any refugees based on the quota system by September 2017. This happened despite the fact that Poland, contrary to the Czech Republic, voted in favour of the refugee quota system. However, this decision was followed by parliamentary elections and the new right-winged government led by the Law and Justice (PiS) party was very critical of the system. Even the then government party Civic Platform (OP) acknowledged that there would be tough negotiations about the quota system. Explicitly against quotas were also the two right-winged parties Kukiz'15 and KORWiN. The liberal party Together was the only one in favour of showing solidarity towards refugees. ${ }^{67}$ From the very beginning, the main problem regarding relocations was that they were legally binding. As the Prime Minister E. Kopacz (OP) said before the elections: "solidarity concerning the division of refugees should be based on the voluntary basis. We don't want this solidarity to be forced solidarity, but, we also don't want this solidarity to be deprived of good will“". ${ }^{68} \mathrm{~A}$ balance between helping but not being pushed to help is desired. Also the following Prime Minister B. Szydło (PiS) stressed that "government will honour EU arrangements as regards refugees, however, the safety of the Poles will be of utmost importance". ${ }^{69}$ The next Prime Minister M. Morawiecki (PiS) highlighted the topos of sovereignty when he repeatedly claimed that: "any relocation of refugees must take place with the consent of the Member States" which "need to have right to decide on

${ }^{66}$ http://www.ceskatelevize.cz/ct24/svet/1529444-zaoralek-kvoty-nechce-stale-vic -zemi-lide-nejsou-zbozi (23.09.2018).

67 K. Narkowicz,'Refugees Not Welcome Here': State, Church and Civil Society Responses to the Refugee Crisis in Poland, "International Journal of Politics, Culture, and Society“ 2018,https://doi.org/10.1007/s10767-018-9287-9 (23.09.2018).

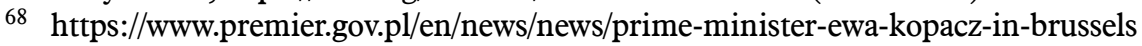
-the-government-will-take-a-decision-on-participation.html (23.09.2018).

69 https://www.premier.gov.pl/en/news/news/prime-minister-beata-szydlo-we-will -take-every-effort-to-make-the-poles-feel-secure.html (23.09.2018). 
whom to accept and whom not" ${ }^{70}{ }^{70} \mathrm{He}$ also stressed that "almost everyone can see that the system of compulsory migrant quotas has beenfaulty at the very heart of its design" ${ }^{71}$ In the Polish discourse, similarly to the Czech one, the topos of burden sharing seems to be conditioned by voluntariness and focus on citizens who need to be protected first.

In line with this, in April 2016, the Sejm issued a resolution in which it criticised relocations and resettlements (especially if carried out as permanent EU mechanisms) and argued that the point of reference should be national criteria decided by Poland solely. At the same time, the Parliament supported sending humanitarian aid to countries affected by conflict and refugee burden..$^{72}$ Since both countries proved to be rather reluctant in participating in relocations, the Commission launched a legal case against them (and Hungary) in June 2017. ${ }^{73}$ During its mandate, the government adopted many laws changing the state of affairs in Poland. Many of them had a broader impact on the whole society (such as the new rules within the Constitutional Court) but regarding refugees, the new surveillance act on antiterrorist activities from June 2016 is of importance. During 2017, the detention rules were widened. Last but not least, Poland tightened controls on its external borders. ${ }^{74}$

This is not to say that the EU cooperation is dismissed completely but it needs to respect national sovereignty: "Europe should be strong in order to better defend our interests, yet the European sovereignty cannot mean building the Union at the expense of the strength of the Member States“ ${ }^{\text {. }}{ }^{75}$ According to Kopacz, there is no "contradiction between taking care of the security of our citizens and offering aid to those who flee war zones to save their lives ${ }^{676}$ since "Poland wants to help. However, we will make our own choice as to who we will help“" ${ }^{77} \mathrm{Kopacz}$ is also the only Prime Minister who explicitly recalls the topos of human rights towards refugees: "turning

70 https://www.premier.gov.pl/en/news/news/prime-minister-mateusz-morawiecki-at-the-meeting-with-the-residents-of-lodz.html (23.09.2018).

71 https://www.premier.gov.pl/en/news/news/prime-minister-mateusz-morawiecki-our-foreign-policy-is-a-policy-of-polish-national.html (23.09.2018).

72 M. Pacek, European Europe - The Migration Crisis of European Integration, "YPES“, vol. 19/2016, pp. 83-100.

73 M. Krzyzanowski, 'Crisis' and Migration in Poland: Discursive Shifts, Anti-Pluralism and the Politicisation of Exclusion, "Sociology", vol. 52(3)/2018, pp. 612-618.

74 W. Klaus, Security First: New Right-Wing Government in Poland and its Policy Towards Immigrants and Refugees, "Surveillance \& Society“, vol. 15(3/4), pp. 523-528.

75 https://www.premier.gov.pl/en/news/news/prime-minister-mateusz-morawiecki-respecting-national-identities-is-the-foundation-for.html (23.09.2018).

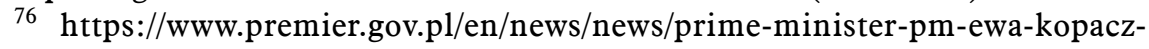
poland-is-and-will-be-safe-pro-european-and-tolerant.html (23.09.2018).

77 Ibidem. 
our back to those who need help in this great European family makes us leave this community morally and mentally“" ${ }^{78}$ Overall, the topos of human rights aims first at Polish citizens whose security should prevail over protecting refugees.

Poland, as the Czech Republic focuses on external solidarity in the sense that it prefers to help countries outside the EU. As Morawiecki says: "Poland shows solidarity through significant involvement in various support programmes for North Africa and Middle East", ${ }^{79}$ and as Szydło adds: "Poland had allocated more funds from the general reserve on humanitarian aid, and in the next year's budget the funds for support to migrants and for humanitarian aid would be higher than in 2016 “ ${ }^{80}$ The topos of human rights seems to be directed outside the EU, like in the Czech discourse.

Poland expressed strong concerns about the majority of refugees being economic migrants since Poland is not able to take care of the latter. As Szydło says: "Refugees who are escaping the threat of losing their lives is one thing, while those who are fleeing for economic reasons is a different matter" ${ }^{81}$ Furthermore, the new government voiced concerns regarding Muslim refugees who were frequently seen as a security risk..$^{82}$ Politicians often argued that Poland cannot repeat the mistakes taken by Western European states where the integration of migrants failed. ${ }^{83}$ Hence, Poland prefers to accept refugees from Slavic coutries such as Ukraine, Chechnya and Uzbekistan.$^{84}$ Indeed, economic migrants and Muslim refugees seem to be excluded from the topos of human rights. The securitisation of the political discourse escalated after the Brussels terrorist attacks in 2016 after which the Prime Minister Szydło stated that no refugees would by accepted by Poland. The topos of security is very much present in the Polish discourse. As Szydło argued: "We offer Europe solidarity in the fight against terrorism and security of the border" ${ }^{85}$ Morawiecki even links security directly to sol-

78 https://www.premier.gov.pl/en/news/news/prime-minister-ewa-kopacz-at-thesejm-solidarity-should-work-in-two-directions.html (23.09.2018).

79 https://www.premier.gov.pl/en/news/news/prime-minister-mateusz-morawiecki -we-strongly-believe-in-a-strong-europe-and-a-strong.html (23.09.2018).

80 https:/www.premier.gov.pl/en/news/news/prime-minister-beata-szydlo-inbrussels-the-eu-ukraine-association-agreement-has-been.html (23.09.2018).

81 https://www.premier.gov.pl/en/news/news/prime-minister-beata-szydlo-we-will -take-every-effort-to-make-the-poles-feel-secure.html (23.09.2018).

82 Cf. K. Narkowicz, op. cit.

83 Ibidem.

84 https://www.premier.gov.pl/en/news/news/prime-minister-mateusz-morawiecki-polish-vision-of-a-united-europe-fits-in-with-the-vision.html (23.09.2018).

85 https://www.premier.gov.pl/en/news/news/prime-minister-beata-szydlo-atthe-meeting-of-the-visegrad-group-in-prague.html (23.09. 018). 


\section{Tab. 2. Czech and Polish construction of solidarity}

\begin{tabular}{|l|l|l|}
\hline \multicolumn{1}{|c|}{ Topos } & \multicolumn{1}{|c|}{ Argumentation strategy } & \multicolumn{1}{c|}{ Topics } \\
\hline $\begin{array}{l}\text { Burden } \\
\text { sharing }\end{array}$ & $\begin{array}{l}\text { The EU and its member states must } \\
\text { control the external EU border and } \\
\text { the most affected third countries } \\
\text { must be helped, particularly by } \\
\text { sending them financial help; refugee } \\
\text { quotas must be voluntary }\end{array}$ & $\begin{array}{l}\text { Refugee quotas, Schengen, } \\
\text { external border control, } \\
\text { cooperation } \\
\text { with 3. countries }\end{array}$ \\
\hline Rules & $\begin{array}{l}\text { All member states must accept } \\
\text { common EU rules; however, state } \\
\text { sovereignty cannot be undermined }\end{array}$ & $\begin{array}{l}\text { Schengen, CEAS, } \\
\text { international law }\end{array}$ \\
\hline Security & $\begin{array}{l}\text { The EU and its member states must } \\
\text { protect the external borders, prevent } \\
\text { irregular migration and fight against } \\
\text { smugglers }\end{array}$ & $\begin{array}{l}\text { Schengen, external border } \\
\text { control, databases, } \\
\text { EU-Turkey agreement, } \\
\text { fight against smugglers } \\
\text { and irregular migration, } \\
\text { return policy }\end{array}$ \\
\hline $\begin{array}{l}\text { Human } \\
\text { rights }\end{array}$ & $\begin{array}{l}\text { The EU and its member states must } \\
\text { protect human rights of refugees; } \\
\text { protection of citizens prioritised; } \\
\text { culturally close refugees preferred to } \\
\text { Muslims; economic migrants explicitly } \\
\text { excluded from protection }\end{array}$ & $\begin{array}{l}\text { Refugee rights, right } \\
\text { to asylum, economic } \\
\text { migration }\end{array}$ \\
\hline
\end{tabular}

NB: Czech and Polish specifics in constructing the topoi are in italics Source: Author's own.

idarity: "Union that is secure, that is, aware of the geopolitical challenges it faces and ready to respond to them with a single voice of solidarity" ${ }^{86}$

Overall, solidarity is cherished as an important value and as a cornerstone of the EU cooperation by Poland. "We are advocates of unity, openness and solidarity. These ideasmotivate the Polish government and we wish to build the EU on them" ${ }^{87}$ Poland also acknowledges the need to follow common rules since "without the rules, it is impossible to build a strong, uniform and solidary EU“. However, it is usually followed by mentioning state sovereignty: "We want to develop a common European system and mechanism that will be acceptable and in line with the spirit of solidarity, $[\ldots]$ - we want, however, to ask our partners to respect certain sensitivities relating to the elements of internal sovereignty“ ${ }^{88}$ The topos of rules is conditioned by ensuring state sovereignty.

86 https://www.premier.gov.pl/en/news/news/prime-minister-mateusz-morawiecki-respecting-national-identities-is-the-foundation-for.html (23.09.2018).

$87 \mathrm{https} / / /$ www.premier.gov.pl/en/news/news/premier-beata-szydlo-chcemy-jednosci -unii-ue-musi-byc-solidarna-i-zjednoczona.html (23.09.2018).

88 https://www.premier.gov.pl/en/news/news/prime-minister-mateusz-morawiecki-close-cooperation-between-poland-and-germany-necessary.html (23.09.2018). 
Similarly to the Czech Republic, also Polandinsists that"the EU refugee relocation scheme has not worked out. Other solutions are required and we want to take part in this discussion" ${ }^{89}$ As Kopacz says: the EU action can not be limited merely to the distribution of refugee quotas. The actions must be comprehensive and include, inter alia, the issues of return policy and border sealing ". ${ }^{90}$ Again, a contradiction is build up between the EU which requires relocation and Poland that strives for a more complex approach. However, as was shown above, the EU approach is much more complex and, apart from relocations, corresponds with the Polish stance. The clash between what the EU wants and what Poland and the Czech Republic expect seems to be, to a large extent, artificially constructed.

\section{Conclusion}

Both the EU and the two selected member states seem to put emphasis on solidarity as an important aspect of a potential solution of the current refugee crisis. However, whereas Poland and the Czech Republic criticise the EU for insisting on a completely faulty refugee quota system, the EU keeps stressing that both countries show a lack of solidarity when they refuse to participate in such a system. Ironically, relocations seem to be the only contested aspect of a more complex solution relying not only on relocations but also on supporting states most affected by the refugee burden, both financially, materially and personally, enhancing external border controls, preventing irregular migration and fighting against smugglers. On all these initiatives, there is an agreement between the EU and Poland and the Czech Republic even though the discourse might seem escalated at first sight.

A closer analysis of how solidarity is discursively constructed seems to be necessary. Employing the DHA, it was explored that the topics covered by the EU and by the two member states are identical. However, as follows from the in-depth analysis, the argumentation strategies vary to a certain degree. Poland and the Czech Republic seem to condition all of the four main topoithat were identified by their own sovereignty and national interests. As Figure 6 shows, both countries, as opposed to the EU, prefer interests and rights of their own citizens and, regarding the topoi of burden sharing and rules, stress that the need for voluntari-

89 https://www.premier.gov.pl/en/news/news/prime-minister-mateusz-morawiecki-our-goal-is-a-thorough-modernisation-of-poland.html (23.09.2018).

90 https://www.premier.gov.pl/en/news/news/meeting-on-the-deepening-eu-migrant-crisis-prime-minister-ewa-kopacz-polands-stance-should.html (23.09.2018). 
ness and non-binding nature in case their sovereignty may be restricted (however, this seems to be a problem in the case of quotas but not regarding external border controls where even more EU involvement is required).

This balancing of solidarity as a value with national interests and focus on security seems to be in line with the theoretical conceptualisation of international solidarity. Indeed, scholars emphasise that solidarity in international relations cannot be expected to be entirely selfless. Simultaneously, they stress that even pursuing its own interests does not need to be in clash with solidarity. Indeed, as the analysis shows, the disagreement is linked almost exclusively to relocations and both Poland and the Czech Republic explicitly declare their willingness to participate in a common EU solution. Now, with the quota system seemingly being obsolete, there might be a new light at the end of the tunnel for a common EU refugee policy.

\section{Tab. 3. Topoi - comparison}

\begin{tabular}{|l|l|l|}
\hline \multicolumn{1}{|c|}{ Topos } & \multicolumn{1}{|c|}{ Agreement } & \multicolumn{1}{|c|}{ Czech and Polish specifics } \\
\hline $\begin{array}{l}\text { Burden } \\
\text { sharing }\end{array}$ & $\begin{array}{l}\text { Controlling external EU border; } \\
\text { sending financial help to third } \\
\text { countries }\end{array}$ & Emphasis on voluntariness \\
\hline Rules & $\begin{array}{l}\text { Focus on following common EU } \\
\text { rules }\end{array}$ & $\begin{array}{l}\text { State sovereignty cannot be } \\
\text { undermined }\end{array}$ \\
\hline Security & $\begin{array}{l}\text { The EU and its member states } \\
\text { must protect the external borders, } \\
\text { prevent irregular migration and } \\
\text { fight against smugglers }\end{array}$ & $\begin{array}{l}\text { Security of Polish/Czech } \\
\text { citizens prioritised }\end{array}$ \\
\hline $\begin{array}{l}\text { Human } \\
\text { rights }\end{array}$ & $\begin{array}{l}\text { The EU and its member states } \\
\text { must protect human rights of } \\
\text { refugees }\end{array}$ & $\begin{array}{l}\text { Protection of citizens } \\
\text { prioritised; culturally close } \\
\text { refugees preferred to Muslims; } \\
\text { economic migrants explicitly } \\
\text { excluded from protection }\end{array}$ \\
\hline
\end{tabular}

Source: Author's own.

\section{References}

Apap J., Carrera S., Maintaining Security within Borders: Towards a Permanent State of Emergency in the EU?, „CEPS Policy Briefs“, no. 4/2003.

Campesi G., The Arab Spring and the Crisis of the European Border Regime: Manufacturing Emergency in the Lampedusa Crisis, „EUI RSCAS Working Papers“, no. 59/2011. 
Carrera S. et al., A Race against Solidarity. The Schengen Regime and the Franco-Italian Affair, „CEPS“, vol. April/2011.

Coicaud J.-M., Wheeler N.J., National Interest and International Solidarity: Particular and Universal Ethics in International Life, United Nations University Press, Tokyo JPN 2008.

Cornelisse G., What's Wrong with Schengen? Border Disputes and the Nature of Integration in the Area Without Internal Borders, „Common Market Law Review“, vol. 51/2014, pp. 741-770.

Crow G., Social solidarities. Theories, identities, and social change, Open University Press, Filadelfie 2002.

De Beer P., Koster F., Sticking Together or Falling Apart? Solidarity in an Era of Individualization and Globalization, Amsterdam University Press, Amsterdam 2009, https://doi.org/10.5117/9789089641281.

Dussel E., From Fraternity to Solidarity: Toward a Politics of Liberation, „Journal of Social Philosophy“, vol. 38:1/2007, pp. 73-92.

Gibbs G., Analyzing Qualitative Data, SAGE, Los Angeles 2018.

Gould C., Transnational Solidarities, "Journal of Social Philosophy“, no. 38:1/2007, pp. 148-164.

Harvey J., Moral Solidarity and Empathetic Understanding: The Moral Value and Scope of the Relationship, "Journal of Social Philosophy“, no. 38:1/2007, pp. 22-37.

Hooker J., Race and the politics of solidarity, Oxford University Press, Oxford; New York 2009, https://doi.org/10.1093/acprof:oso/97801953353 61.001.0001.

Chong D., Rogers R., Racial Solidarity and Political Participation, „Political Behavior“, no. 27:4/2005, pp. 347-374.

Klaus W., Security First: New Right-Wing Government in Poland and its Policy Towards Immigrants and Refugees, „Surveillance \& Society“, vol. 15(3/4), pp. 523-528, https://doi.org/10.24908/ss.v15i3/4.6627.

Krieg A., Motivations for Humanitarian Intervention: Theoretical and Empirical Considerations, Springer, Heidelberg 2013, https://doi.org/10.1007/97894-007-5374-7.

Krzyzanowski M., 'Crisis' and Migration in Poland: Discursive Shifts, AntiPluralism and the Politicisation of Exclusion, „Sociology“, vol. 52(3)/2018, pp. 612-618.

Krzyżanowski M., International leadership re-constructed? Ambivalence and heterogeneity of identity discourses in European Union's policy on climate change, "Journal of Language and Politics“, vol. 14:1.

May L., The International Community, Solidarity and the Duty to Aid, „Journal of Social Philosophy“, vol. 38:1/2007, pp. 185-203. 
Narkowicz K., Refugees Not Welcome Here': State, Church and Civil Society Responses to the Refugee Crisis in Poland, „International Journal of Politics, Culture, and Society“ 2018, https://doi.org/10.1007/s10767018-9287-9.

Pacek M., European Europe - The Migration Crisis of European Integration, „Yearbook of Polish Eeuropean Studies“ 2016, vol. 19/2016, pp. 83100.

Pensky M., The ends of solidarity: discourse theory in ethics and politics, State University of New York Press, Albany 2008.

Rehg W., Solidarity and the Common Good: An Analytic Framework, ,Journal of Social Philosophy“, vol. 38:1, 2007, pp. 7-21, https://doi. org/10.1111/j.1467-9833.2007.00363.x.

Reisigl M., Argumentation Analysis and the Discourse-Historical Approach. A Methodological Framework, in: Contemporary Critical Discourse Studies, eds. C. Hart, P. Cap, Bloomsbury London 2014.

Rippe K.P., Diminishing Solidarity, „Ethical Theory and Moral Practice“, no. $1 / 1998$, pp. 355-374.

Shelby T., We who are dark: the philosophical foundations of Black solidarity, Belknap Press, Cambridge MA 2012.

Scholz S., Political Solidarity and Violent Resistance, „Journal of Social Philosophy“, no. 38:1/2007, pp. 38-52.

Tulmets E., Identities and Solidarity in Foreign Policy: East Central Europe and the Eastern Neighbourhood, Institute of International Relations, Prague 2012.

Wilde L., The Concept of Solidarity: Emerging from the Theoretical Shadows?, „BJPIR“, no. 9/2007, pp. 171-181.

Wodak R., Krzyżanowski M., Qualitative Discourse Analysis in the Social Sciences, Palgrave Macmillan, Basingstoke; New York 2008, https:// doi.org/10.1007/978-1-137-04798-4. 